\title{
Construction of Indonesian Muslim Identity in Photo News in National Newspaper in Medan City
}

\author{
Muhammad Said Harahap ${ }^{1}$, Syukur Kholil ${ }^{2}$, Iskandar Zulkarnain ${ }^{3}$ \\ 1,2,3 Universitas Islam Negeri Sumatera Utara, Medan, Indonesia \\ muhammadsaid@umsu.ac.id
}

\begin{abstract}
The presence of news photos that appear in print media plays a role in providing strong and accurate information that can contribute creativity and ideas, able to communicate messages through information channels to a mass audience. The research method used in this study is qualitatively descriptive with Roland Barthes's semiotic approach. The results of this study suggest that the news of ramadan and homecoming photos that take place once a year is able to create the meaning of social construction of Indonesian Muslim identity simultaneously a full month brings a positive message through the delivery of messages of kindness at routine activities carried out by Muslims in Indonesia. The marking of denotations, connotations and myths of its nature is everywhere the news of ramadan and homecoming events has become a part of the daily life culture of Indonesian Muslims so that through the structure of meaning that is included in the news photos peritiwa Ramadhan and Mudik has become guidelines and guidance for people in obtaining information on the meaning of the sign of the information needed and desired after publicity became the headline of the National Newspaper in Medan, among others, The Analisa Newspaper and Waspada Newspaper.
\end{abstract}

Keywords

construction; Indonesian muslimidentity, newsspaper

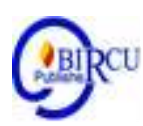

\section{Introduction}

News Photos in the face of the mass media pages especially newspapers are not just supporters of content in the news. The presence of photo news that appears presented so that publicity in print media plays a role to provide strong and accurate information and use photo news can contribute creativity along with ideas, able to communicate messages through information channels to the mass audience, influence anyone, can present information channels in the world of journalists so as to strengthen the readers' memories of messages delivered through newspaper news channels.

Visual news photos as an information channel of Ramadan events and homecoming of Indonesian Muslims are able to describe the situation felt by Indonesian Muslims who want to return home to make a visit and make a pilgrimage to the tomb of the family ancestors. The intention and purpose of selecting the three national newspapers is because it is a regular agenda to publish news photos about the events of the holy month of Ramadan and Homecoming of Eid al-Fitr of Indonesian Muslims in The Analisa Newspaper and Waspada Newspaper. Through consideration of the three national newspapers is the print media that has the highest number of oplah and has become a reference to the majority of readers both from academia, public officials, politicians, social observers, students and broad of people. 
These two national newspapers also raised events that occurred around North Sumatra, one of which is the phenomenon of the holy month of Ramadan and Homecoming eid al-Fitr of Indonesian Muslims. Many unique phenomena in the holy month of Ramadan and Homecoming eid al-Fitr of Indonesian Muslims are publicly publiced in photo news in The Analisa Newspaper and Waspada Newspaper thus the process of information travel during this time, such as news photos can be said to visually photograph reality in human activity and the visual content of photos obtained by journalists can be said to in no way engineer the manipulation of points of interes to show events in natural and as the willingness of the photojournalism or, in the case of the photojournalism there is certainly no setting or engineering of the object in order for the event to occur naturally and naturally according to the wishes of the photographer, everything happens naturally. Photo journalists can be said to be factual, because it includes elements of meaning and signs that exist in the events that occur.

\section{Review of Literatures}

\subsection{Communication}

Humans generally interact in society, from the beginning of waking up to sleeping again, co-committally in society, naturally always involved in communication . Society consists of at least two people who are related to each other and bring about social interaction (intercommunication). Communication is a process for the delivery of a stimulus from an individual to another individual for the purpose of informing or changing the response or attitude, view, opinion or behavior, either in oral form or indirect form i.e. through other media or channels. Batubara (2019) states that Communication is one part of the relationship between humans both individuals and groups in everyday life1, from this understanding is clear that communication involves a number of people where one expresses something to other people, so who is involved in communication is the man himself.

The definition of communication is common. The term communication is absorbed from Latin, which is communicatio which means exchange or can be called notification. The adjective is communis, which has the same or general meaning. Simply put, if one wants to convey a message of communication to others then it is good to agree the equation of code, symbol or symbol with the intended person as the purpose of the communication message. Shanon and Weaver say communication is a form of human interaction that affects each other, intentionally or unintentionally and is also not only limited to oral communication, but also in terms of facial, technological, painting and art reactions2. Book describes the definition of communication specifically in the study of human communication, shows that communication is a form of transaction, a symbolic process that allows people to organize their own environment of residence by (1) establishing interactions or social relationships between social beings, (2) conducting information exchanges, (3) to strengthen the attitudes and behaviors of others, (4) and attempt to change that attitude and behavior. 3

\subsection{Mass Communication}

Mass communication that we understand is currently imported from the origin of foreign language words, namely Mass communication, the origin of the abbreviation mass media communication or called mass media communication in English terms that is communication that uses the means of mass media in practice. So the term of mass 
communication can be said as a means and channel that is mass media taken from the abbreviation of media of mass communication. It can be said that mass communication is one of the activities of communication activities that is practically done by using mass media of communication. So mass communication is communication with the mass audience or the audience of the community.

Society has the meaning of a lot of people although they don't always have to gather at the same point. They can spread or separate from different locations but in the same time get similar or even the same communication messages.

Mass communication funnels ideas, attitudes and ideas to the recipients of messages (communion) there are a wide variety of uses of media. The identity of mass communication that are:

\section{The Messager in Institutional Communication}

The messenger or also referred to as the communicator in a mass communication does not refer to a single recipient, can be interpreted as a group of people of various elements and they work with each other in an institution. The institution here in question resembles a system. Let's say that network is a bunch of people. Guidelines and media that conduct an activity of processing, storing, pouring symbols, ideas, emblems, gaggasan, into messages in making decisions to reach one common ground and agreement with each other by processing messages into sources of information.

2. The messenger in mass communication is dual

Explanation is an audience of different genders ages, economies, has diverse positions, education, and social status, and adheres to a diverse tradition of beliefs or religions.

\subsection{Photography}

The word Photography is absorption of two syllables of English photography, which is derived from the Greek word "photoss" meaning light/rays while "grafo": striping or writing the definition of photography itself tends to be the activity or production process of a visual image photographing an object, while the photographer is the one who performs thegitan or photography activity. A photographer is an activity that is commonly said by people whose lives are always side by side with photogrfi and photography a process of freezing objects using light. Another term photography is the documentation of objects through the process or method As a general term, photography means a process or method to produce visual images on an object with the utilization of light reflections be it natural light sunlight as well as the utilization of artificial light called incandescent lamps so as to produce good images.

Photo Journalist according to University of Missouri, USA Professor Cliff Edom is a dialeg unification of words and pictures. Around 1937-1950 a life magazine editor known as Wilson Hick said a mixture of dialeg words and visuals had a meaning that created a relationship at a time of conformity from the context of knowledge and social aspects of newspaper readers. Image copyright Ap Image caption There are eight types according to Walter Cronkite, an expert from the University of Arizona's School of Journalism and Telecommunications in a book called Photojournalism the visual approach.

\subsection{Semiotic}

Roland Barthes was one of those structuralist thinkers who practiced saussurean linguistic and semiological models. Barthes is also known as a renowned French intellectual and literary critic; exponent of the application of structuralism and semiotics to literary studies. One of the areas Barthes worshipped in his study of signs was the role of 
the reader. Connotations, although they are the original nature of the sign, require the reader's liveliness to function. Barthes at length reviews what is often referred to as a second state-of-the-table system, built on top of other systems that have existed before. This second system by Barthes is called connotative, which in his Mythologies expressly distinguishes from the denotative or the system of meaning of the first state. Continuing Hjelmselv's studies, Barthes created a map of how to mark

In his description, Barthes points out that this myth in this particular sense is a development of connotations. Long-established connotations in society are myths. Barthes also says that myth is a semiological system, a system of signs defined by man. Myth can also be said to be a product of social class that already has dominance. So the myth in Barthes's view in itself is different from the myth that we consider superstitious, absurd, ahistorical, etc., but a myth according to Barthes as a type of speech. Examples of myths in Roland Barthes's view; Wine according to Barthes in the first layer of expression means "alcoholic drink made from grapes" But in the second layer of wine can be interpreted as a characteristic of the 'pranci-san' that the people of the world give to this type of munuman. The dominant society has always considered French wine, whereas many other countries also produce similar munuman, based on the example given, Barthes wants to show that the symptoms of a culture can acquire connotations according to the point of view of a society, If the connotations are established, then it will become a myth, whereas a firm myth will become idiology. Roland Barthes says meaning using objects not only carries information, in terms of where objects suddenly communicate, but also unconstitutionals the structured system of signs.

Table 1. Pictures Roland Barthes's Sign Map

\begin{tabular}{|c|l|}
\hline $\begin{array}{l}\text { 1. Signifier } \\
\text { (Penanda) }\end{array}$ & $\begin{array}{l}\text { 2. Signified } \\
\text { (Petanda) }\end{array}$ \\
\hline $\begin{array}{c}\text { 3. DenotatifSign (tanda } \\
\text { denotatif) }\end{array}$ & \\
\hline $\begin{array}{c}\text { 4. Connotative Signifier (Penanda } \\
\text { Konotatif) }\end{array}$ & $\begin{array}{l}\text { (5).Connotative Signified (Petanda } \\
\text { Konotatif) }\end{array}$ \\
\hline 6. Connotative Sign (Tanda Konotatif) \\
\hline
\end{tabular}

Barthes points out in one of the essays titled The Photographic Message connotations in a photograph can arise through six procedures that can be categorized into two parts. First, engineering can directly influence reality itself. This engineering includes trick effects, poses, and object selection. Second, engineering is included in the "aesthetic" region, consisting of photogenia, aestheticsm, and syntax.

1. Trick Effect (kayaking photo visuals) is an action performed with the aim of manipulating the results of a photo such as adding, reducing, or changing the objects contained in the photo so that it becomes a different image and has a different meaning.

2. Pose is the attitude, gesture and expression of an object based on the stock of signs of a particular society that has a certain meaning as well.

3. Objects are objects or objects composed in such a way that they can be associated with certain ideas, such as, for example bookshelves are often associated with intellectuality.

4. The art of photographing so that the resulting photo has been "spiced" or decorated with ligthing, exposure, and printing techniques. Colors, bluring techniques, panning or motion effects are also included here. 
5. Framing or aesthetics related to the overall composition of the image that give rise to a certain meaning.

6. Original Files are usually present in a series of photos displayed in a single title, where time no longer appears on each photo, but on the entire photo displayed, especially when associated with the main title.

\section{Research Methods}

The research method in this study used by researchers is a qualitative descriptive research method using a semiotic analysis approach. The focus of this research was carried out on the news of the holy month of Ramadan and the homecoming of Indonesian Muslims published and published in The Analisa Newspaper and Tribun Medan Newspaper in 2019. Furthermore, the researchers proceeded to find out about the truth of the news of the event photos from the photographer and editor of the photo responsible for the photographs that were publicly released in the Analisa Newspaper and Waspada newspaper.

\section{Discussion}

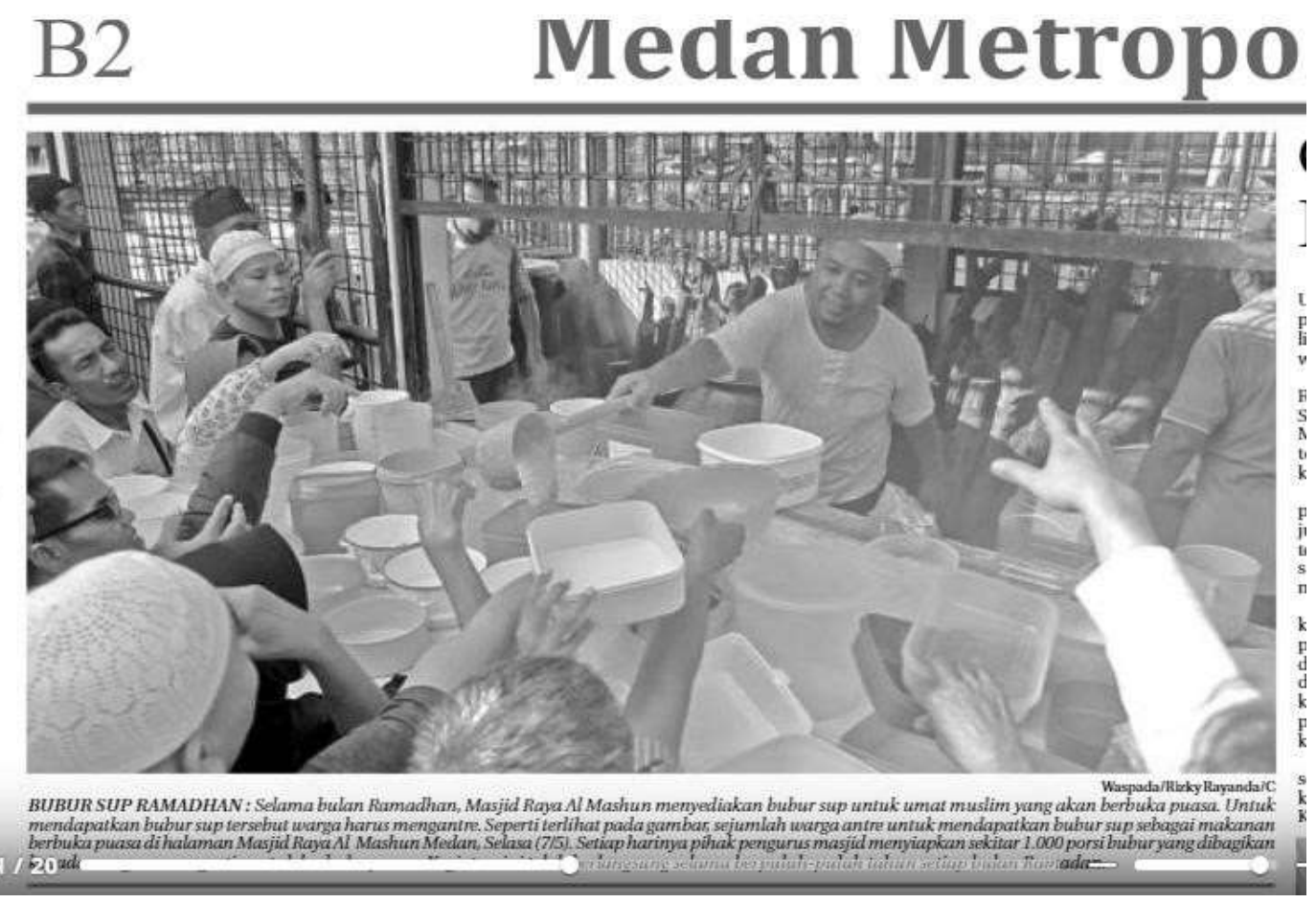

Figure 1. News Photos in Waspada Newspaper Tuesday $7^{\text {th }}$, 2019 Edition

The Newspaper Waspada presents photo news with the theme of the story Bubur Sup Ramadhan, during Ramadan 1440 H Masjid Raya Al'Mashun provides soup porridge for Muslims who will break the fast. To get the soup porridge, residents were forced to queue as seen in the picture of a number of people queuing to get soup porridge as an iftar meal menu in the courtyard of the Al'Mashun Medan Grand Mosque. Every day in Ramadan $1440 \mathrm{H}$ the mosque manager prepares 1000 portions of porridge for the iftar meal menu. The Waspada newspaper published this photo in Tuesday, May 7, 2019 with a wide horizontal shot from a position almost parallel to objects such as medium anggle or 
that indicates the crowd is full and crowded as it looks dramatic, emotionally occurring in this moment of important event and this photo also shows the black and white color of indonesian muslims' clothes sticking out by holding bowls while queuing to get a special distribution of soup porridge typical of malay royal cuisine Sultan Deli in the courtyard of the Mosque Raya Al'Mashun Medan as an iftar menu of Ramadan $1440 \mathrm{H}$ at Masjid Raya Al'Mashun and Masjid Raya Al'Mashun 2 th year provides about 500 kilograms of traditional Malay ingredients in the form of porridge soup and also prepares about 500 to 1,000 takjil every day diving the holy month of Ramadan $1440 \mathrm{H}$. while a number of children were seen taking part in the iftar with Muslims in the holy month of Ramadan $1440 \mathrm{H}$ and are seen in the photo queuing Indonesian Muslims are seen enjoying the atmosphere of fighting each other the distribution of porridge rations provided by the flooded committee of Al'Mashun Medan Grand Mosque so that this photo looks to form a dramatic colossal. This photo of the Waspada Newspaper by photographer Riky Rayanda is displayed on the city's rubric page of Waspada newspaper. Therefore, it can be seen that The Waspada newspaper wants to show the atmosphere of the holy month of Ramadan $1440 \mathrm{H}$.

\subsection{Denotative Meaning}

This photo shows the situation of Indonesian Muslims looking patiently waiting for the distribution of soup porridge as an iftar menu in the Holy month of Ramadan $1440 \mathrm{H}$ although in simple conditions the distribution of soup porridge is always eagerly awaited muslims so that it melts into the soul and Indonesian Muslims look like putting hope of enjoying the traditional soup porridge down from the Malay Kingdom sultan deli after serving in the holy month of Ramadan $1440 \mathrm{H}$.

\subsection{Connotative Meaning}

As discussed above the semiotic analysis to discuss the visual news connotations of the image will present six factors and divided into two parts one is to engineer the visional of the overall image can give rise to the state of the event, engineering in tirck content, effects, style and determination of points of interes. Second, engineering contributes to the scope of the "ethical" area of Photogenia, estheticsm and sintaxis. I

First it will be discussed for trick effect (image manipulation) can be said to include other elements, scroping as well as changing the content of points of interest in the visual image can ultimately make the compost become different so that the meaning must be different as well. The actual application of the photo journalist is not allowed to engineer because even how the photo of the journalist is a photo taken based on fact and without engineering, the photo journalist records any form of action or event that occurs spontaneously. However, if it is limited to cropping, or object lighting, it is legal to do so.

This is according to the editor of the photo Waspada newspaper Muhammad Faisal told the researchers "The manipulation is limited to cropping, and the lighting settings are legitimate only, as long as do not change the meaning of the authenticity of the photo, for example, the flooded officers of Al'Mashun Grand Mosque handed out porridge soup to the patient citizens waiting in line for the distribution of traditional malay specialties that have been done since 1909 sultan deli kingdom has been handing out iftar menus at Al'Mashun Medan Grand Mosque, incidentally, photojourna reporters take the atmosphere of the mass queue of Indonesian Muslims crammed in order to obtain porridge that is said to be very effective for the health of the body, especially during the fasting period during the holy month of Ramadan, the display of the child's hand is seen patiently waiting for the distribution of porridge, while the required image should be a close up on the object of 
the soup's porridge division queue, so it is necessary to manipulate cropping. (interview, Tuesday 6 April 2020)

The image above is visible if photo manipulation such as reducing, adding, or changing objects is not performed. Only a little cropping is done, it is intended to sharpen or focus the object of the atmosphere of breaking the fast in the holy month of Ramadan $1440 \mathrm{H}$, When the moment of the photo occurs, the narrowing of the space affects the reader who will remain focused on the main object or in the term photography point of interest.

Second, the pose is gesture. The presence of a scattering style of expression points of interes includes the condition of stock of sings looks the face of the crowded khlayak so as to present an implied meaning. The attitude seen in this picture of Indonesian Muslims is seen waiting for the distribution of traditional Malay food typical of the Sultan's Deli Kingdom as an iftar meal of Ramadan $1440 \mathrm{H}$ and muslims melt in the joyful joy of each other together preparing takjil food. The above attitude means if a man has got something valuable and wants to keep the situation and security conducive.

Third, the placement of objects is the objects or arrangements of supporting objects that are included in the composition done by many photographers have methods or ideas that can brief the reader. From this displayed image, objects that associate with certain ideas.

Fourth, photogenia is part of engineering the points of interest capable of visually inserting the element by inserting a lighting menu, setting the entry of light and printing resulting in color and bluring bluring bokeh methods as well as motion mode or motion effect panning also included here.

Exposure is the lighting process in the afternoon, and related events in this photo occurred in the open space area of Masjid Raya Al'Mashun Medan mosque one of the largest mosques in North Sumatra as well as the icon of Medan City as a symbol of the identity of the establishment of Islamic civilization in Medan city so that the lighting light is able to cover the open area of the mosque a lot of light in. So exposure relies solely on natural light from the lighting of the mosque room light, the diaphragm scale is F4.5 to 11 $\mathrm{mm}$ following the existing light, iso 400 and the shutter speed scale is around 1/100 s.

Fifth, Aesthetics or aesthetics can be said to be related to the preparation of a number of objects into the frame of the image (composition) and dapay presents the implied meaning in the visual image above the preparation of objects with a background balanced 3/4 in the contents by the mass image of Indonesian Muslims from various circles and educational background blending antrea to simply get traditional Malay food sultan deli kingdom.

Sixth, the presence of the entire visual content of the image and appeared on one photo news theme, when at the time of the next unsanimity of the visual image respectively. However, from the entire visual form of the image that appears there is a visual content of the image that the researchers analyzed based on what is listed on the photo caption. Syntax itself can be analyzed through coherence, sentence shapes, and pronouns. Mythology is the term Barthes uses, to distinguish the concept presented by him from the myth of the traditional version. Mythology is a modern myth, where the aspect of 'logos' (rational or scientific thinking) is included. So, the myth of the old version is all stories that are absurd but believed to be true by a society.

Roland Barthes, reconstructing the meaning contained in a sign by understanding the meaning of denotation as the first state, then connotations as a second state that is a meaning related to feelings and emotions and cultural values and ideologies that give birth to myths that are a way of thinking culturally about something, a way to conceptualize or 
understand something. The unique series of traditional malay food distribution events that have been known since hundreds of years ago where the Sultan's Deli Kingdom routinely divides the food during Ramadan which is divided into masses of Indonesian Muslims is actually the culture and identity of Indonesian Muslims that has been done for a long time and until now is still carried out this is strengthened and considered a declining tradition.

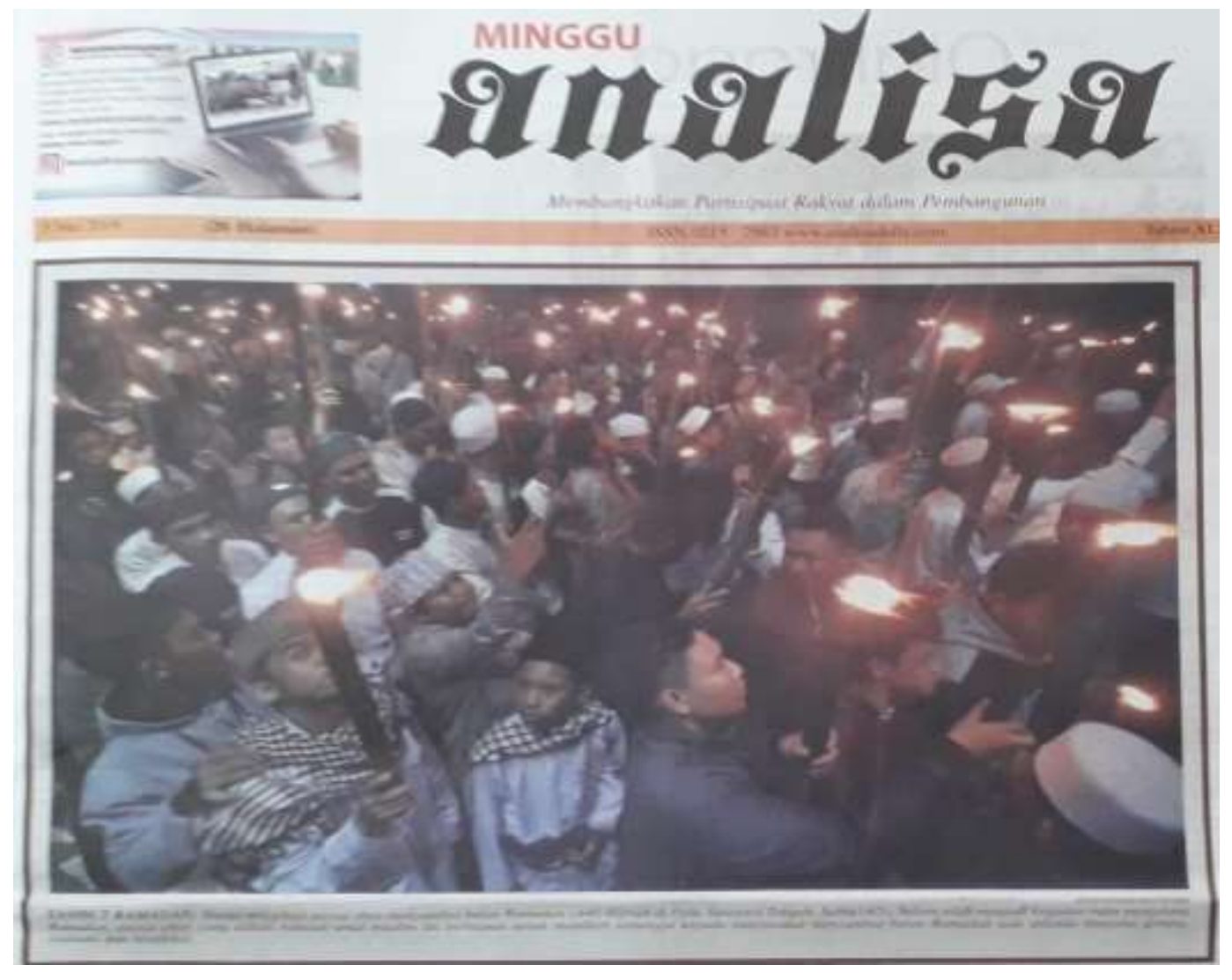

Figure 2. News Photos in Analisa Newspaper, Sunday 5th May 2019 Edition

Analisa newspaper presented this photo with the theme of Torch Fire March in the Sunday issue of May 5, 2019 with a wide horizontal wide shot from a higher position such as a staircase or building that signifies thousands of masses of Indonesian Muslims impressing full and crowded as seen dramatic impressions, emotional feeling occurred in this moment of important event and this photo news also shows the colorful clothing of Indonesian Muslims lit by the light of torch fire carried by the masses with bamboo container stalks, while other people watched the torch fire parade with a sense of joy, to welcome the night of the holy month of Ramadan $1440 \mathrm{H}$ and seen in the photos of thousands of Indonesian Muslims as well as the public as if not feeling the rainy weather accompanied by cold air at night so that this photo looks to form a dramatic colossal. This photo by Ferdy Siregar was featured as the headline of the first page of The Analisa Newspaper. Therefore, it can be seen that The Analisa Newspaper wants to show the Identity of Indonesian Muslims carried by the atmosphere of the night welcoming the holy month of Ramadan $1440 \mathrm{H}$. The condition of the excitement and excitement of Indonesian Muslims is created to welcome the event once a year, the event that is awaited and always mentioned in the prayer of Indonesian Muslims to Allah SWT in order to be able to reunite with the holy month of Ramadan $1440 \mathrm{H}$, especially Indonesian Muslims in Medan 
City. The display perfectly packed news photos that have high emotional value thus forming a dramatic colossal.

This photo shows the condition of the torch fire march participants despite the drizzle but the spirit of Indonesian Muslims in welcoming the first day of the holy month of Ramadan $1440 \mathrm{H}$ is unstoppable so that it melts into the soul and Indonesian Muslims look like they are putting hope of a better life change in the end after undergoing worships in the holy month of Ramadan $1440 \mathrm{H}$.

\subsection{Connotative Meaning}

As discussed above the semiotic analysis to discuss the connotations of visual news the image will present six factors and divided into two parts one is to engineer the visional of the overall image can cause changes in the state of the event, engineering in tirck content, effects, style and determination of points of interes. Second, engineering contributes to the scope of the "ethical" area of Photogenia, estheticsm and sintaxis.

First it will be discussed for trick effect (image manipulation) can be said to include other elements, scroping as well as changing the content of points of interest in the visual image can ultimately make the compost become different so that the meaning must be different as well. The actual application of the photo journalist is not allowed to engineer because even how the photo of the journalist is a photo taken based on fact and without engineering, the photo journalist records any form of action or event that occurs spontaneously. However, if it is limited to cropping, or object lighting, it is legal to do so.

This is according to the editor of the photo rubric of The Analisa newspaper Ferdy Siregar, he explained "The manipulation is cropping, and the lighting settings are valid, as long as it does not change the meaning of the authenticity of the news events of the photo. For example, the visual image at an event of thousands of Indonesian Muslims conducting a torch fire march welcoming the first night of the Holy month of Ramadan $1440 \mathrm{H}$, incidentally the photojour reporter took the atmosphere of thousands of Indonesian Muslims doing a torch fire march welcoming the holy month of Ramadan $1440 \mathrm{H}$, while the required image should be a closeup of the mass object of the torch fire march, so it is necessary to do cropping manipulation. (Interview, Tuesday 5 May 2020)

The images in the explanation above the photographer do not perform engineering such as reducing the elements in the photo or changing and enhancing other elements in the composition of the photo news frame. Only a little cropping was done, it was intended to sharpen or focus the image of indonesian Muslims doing torch fire marches, boisterous conditions and situations and many Indonesian Muslims carrying torch fire with bamboo containers and then mass marchers around Medan by tracing the streets of the city's core while circling the homes of residents the torch fire march was carried out with joyful joy and the starting point of the torch fire march trip welcoming the eve of the holy month of Ramadan $1440 \mathrm{H}$, starting from the page of $\mathrm{Al}^{\prime}$ Mashun Grand Mosque, Medan City. When the moment of the photo occurs, the narrowing of the space affects the reader who will remain focused on the main object or in the term photography Point of Interest.

Second, the pose is gesture. The presence of a scattering style of expression points of inters includes the condition of stock of sings seen the face of the crowd so as to present an implied meaning. The attitude seen in this image of Muslims as participants of torch fire marches and the wider community as spectators melt into one in joyful joy to join each other and melt in the situation of the moment of excitement.

Third, the placement of objects is the objects or arrangement of supporting objects that are included in the composition done by many photographers have methods or ideas that can brief the reader. From this displayed image, objects that associate with certain 
ideas. In the photo, the association that there has been a story of a unique phenomenon in the great event done by thousands of Indonesian Muslims.

Fourth, photogenia is part of engineering the points of interest capable of visually inserting the laian element by inserting a lighting menu, setting the entry of light and printing resulting in color and bluring bluring bokeh methods as well as motion mode or motion effect panning also included here. So exposure relies solely on natural light from highway lighting and torch fire carried by thousands of participants, the diaphragm scale is F 2.8 to $3.5 \mathrm{~mm}$ following the existing light, iso/asa 1600 strength and the shutter speed scale seems slow ranging from $1 / 60$ Sec.

Fifth, Aesthetics or aesthetics can be said to be related to the preparation of a number of objects into the frame of the image (composition) and can present the implied meaning in the visual image above the preparation of objects with a balanced background, 3/4 filled by images of thousands of masses of Indonesian Muslims who gathered to perform a torch fire march welcoming the night of the holy month of Ramadan $1440 \mathrm{H}$.

Sixth, the presence of the entire visual content of the image and appeared on one photo news theme, when at the time of the next unsanimity of the visual image respectively. However, from the entire visual form of the image that appears there is a visual content of the image that the researchers analyzed based on what is listed on the photo caption. Syntax itself can be analyzed through coherence, sentence shapes, and pronouns. The presence of modern myths is the result of Rolan Barthes's reconstruction to distinguish forms from traditional versions of the term "Mythology". Modern myths are a re-reconstruction of traditional model myths that include other forms such as "logos" (rational or scientific thinking). According to Barthes the myth of the traditional model is a form of story that is superstitious or does not enter the realm of thought but the traditional society believes its justification by the community.

\section{Conclusion}

News photos of Ramadan and Homecoming that take place once a year are able to create the meaning of social construction of Indonesian Muslim identity simultaneously a full month brings a positive message through the delivery of good messages on routine activities carried out by Muslims in Indonesia. The marking of denotations, connotations and myths is the nature of the news photos of Ramadan and homecoming events have become a part of the daily life culture of Indonesian Muslims, so that through the structure of meaning that is included in the news photos peritiwa Ramadhan and homecoming has become guidelines and guidance for people in getting information on the meaning of the sign of the information needed and desired after publicity became the main news of the National Newspaper in Medan, among others, The Analysis Newspaper, Newspaper Waspada. Ramadhan and Mudik photo news text becomes a unique phenomenon that occurs once a year in this event as a sign of giving us print media readers something else (socio-cultural values maintained and maintained to this day and as a refrecentation of denotation, connotations, myths and idiology) that is humane to us. 


\section{References}

Ahmad Musthafa Al-Maraghi, Tafsir al-Maraghi, 2003. Thoha Putra, Semarang

Alwi, Audy Mirza. 2004, Foto wartawan, Metode Memotret dan Mengirim Foto ke Media Massa. PT. Bumi Aksara,Jakarta

Al-Maraghi, Ahmad Musthafa, Tafsir Al-Maraghi, terj. Anshori Umar Sitanggal, dkk. Semarang: Karya Toha Putra, cet. Ke-2, 1993, juz 11.

Andre Moller,2005, Ramadhan in Java: The Joy and Jihad of Ritual Fasting:Nalar

Ar-Rifa'i, Muhammad Nasib. 2007. Kemudahan dari Allah: Ringkasan Tafsir Ibnu Katsir Jilid I. Jakarta: Gema Insani

Asep Effendy, 2013, Amazing Photo With Photoshop: Mediakita Jakarta

Audy Mirza Alwi.2009. Metode Memotret dan Mengirim Foto ke Media Massa. Jakarta: Bumi Aksara.

Barthes, Roland. 1978, Image Music Text, Hill and Wang, New York

Batubara, M. U., Lubis, L., and Kholil, S. (2019). Islamic Communication Pattern of Judges in Dealing Conflict of Muslim Families in the Religious Court Medan. Budapest International Research and Critics Institute-Journal (BIRCI-Journal) Vol 2 (1): 373-386

Benny H. Hoed. 2011. Semiotik dan dinamika sosial budaya, Second Edition. Depok: Komunitas Bambu. Depok: Fakultas Ilmu Pengetahuan Budaya Universitas Indonesia.

Berger, Arthur Asa. 2005. Tanda-tanda dalam Kebudayaan Kontemporer, Suatu Pengantar Semiotika. Yogyakarta:Tiara Wacana Yogya.

Burhan Bungin, 2011, Konstruksi Sosial Media Massa. Kencana.Jakarta

Burhan Bungin. 2008. Sosiologi Komunikasi Teori, Paradigma, Diskursus Teknologi Komunikasi di Masyarakat Kencana, Jakarta

Cangara, Hafied. 2004. Pengantar Ilmu Komunikasi, Jakarta, PT. Raja Grafindo. Persada.

Edison Paulus, 2012. Still Life Photography. Jakarta: Elex Media Komputindo Kompas Gramedia Jakarta

Eriyanto, 2011. Analisis Wacana, Pengantar Analisis Teks Media, LKIS, Yogyakarta.

Husaini Usman, 2009. Metodologi Penelitian Sosial: Bumi Aksara, Jakarta

Ibnu Qayyim, 2003, Tafsir Al-Qayyim, Beirut Dar ast Tsaqaf,

Idrus, Muhammad. 2009. Metode Penelitian Ilmu Sosial: Pendekatan Kualitatif dan Kuantitatif. Jakarta: Erlangga

Iskandar, M. \& Atmakusumah, 2004. Panduan Jurnalistik Praktis. Lembaga Pers. Dr. Soetomo, Jakarta

Jamal Mildad 2016 vol, 2, no2, http:// jurnal.utu.ac.id/ jsource/ article /view/ 300/ 263Journal Source E-ISSN : 2502-0579 ISSN : 2477- 5789

John Fiske. 2010. Cultural and Communication Studies: Sebuah Pengantar Paling Komprehensif. Yogyakarta, Jalasutra

Kholil Syukur, 2016.Metodologi Penelitian Komunikasi.Perdana Publishing Medan

Kholil, Syukur. 2007. Komunikasi Islam.Citapustaka Media, Bandung.

Koentjaraningrat, S.1997. Metode Penelitian Masyarakat. Jakarta: PT. Gramedia

Muhammad Nasib ar-Rifa'i, Ringkasan Tafsir Ibnu Katsir, Gema Insani, 2007. Jakarta

Komala, L, 2009, Ilmu Komunikasi, Perspektif, Proses, dan Konteks, Widya Padjajaran, Bandung.

Kriyantoro, R, 2010. Teknik Praktis Riset Komunikasi, Kencana Prenada, Jakarta.

Kurniawan. 2001. Semiologi Rolland Barthes. Magelang: Indonesia Tera. 
Kusuamaningra, P, \& Kusuaaningrat, H. 2009, Jurnalistik Teori dan Praktek, Rosda Karya, Bandung.

Mc.Quail, D, 1991, Teori Komunikasi Massa. Erlangga, Jakarta

Michael, Flournoy, Don. 1989. Analisis Isi Media cetak-Media cetak Indonesia. Yogyakarta: Gajah Mada University Press

MM Hikmat. 2007. Metode Penelitian Dalam Perspektif Ilmu Komunikasi dan Sastra, Bandung, Grafitri

Moleong, Lexy J. 2013. Metode Penelitian Kualitatif. Edisi Revisi. Bandung: PT. Remaja Rosdakarya.

Morrison, Wardhani. C.H. \& Hami, F, 2010, Teori Komunikasi Massa, Ghalia Indonesia, Bogor

Mulyana, Dedi. 2018. Ilmu Komunikasi Suatu Pengantar Karya, Bandung

Mulyana, Dedi, 2011. Komunikasi Lintas Budaya. Remaja Rosda Karya Bandung

Mulyana, Dedi. 2007. Metode Penelitian Komunikasi, Contoh-Contoh Penelitian Kualitatif dengan Pendekatan Praktis, Remaja Rosda Karya Bandung.

Muhammad. 2009. Metode Kualitatif Penelitian Bahasa. Liebe Book Press. Yogyakarta

Nasution. 1996. Metode Penelitian Kualitatif Naturalistik. Jakarta: Sinar Grafika

Nurudin, 2004. Pengantar Komunikasi Massa. Jakarta. PT. Raja Grafindo Perkasa,

Onong Uchjana Effendi. 2004. Dinamika Komunikasi. Bandung Remaja Rosdakarya.

Pawito. 2007. Penelitian Komunikasi Kualitatif. Yogyakarta: Pelangi Aksara. Yogyakarta

Purbayu, Budi, dan Mulyawan Hamdani, 2007, Statiska Deskriptif dalam Bidang Ekonomi dan Niaga. Jakarta: Erlangga

Samovar, L.A, Porter, E.R., R., \& McDaniel R.E, 2010. Komunikasi Lintas Budaya. Salemba Humanika Jakarta.

Saverin J.W. \& Fossa, A.K, 2008. Teori Komunikasi, Sejarah, Metode, dan Terapan di dalam Media Massa, Kencana Prenada, Jakarta

Scott Kelby, 2014. Photo Recipes Live Dibelakang Layar: Elex Media Komputindo, Jakarta

Setiadi, Teguh. 2017. Dasar Photography: Cara Cepat Memahami Photography. Yogyakarta: Andi Offset.

Sobur, Alex. 2013. Semiotika Komunikasi. Bandung: PT Remaja Rosdakarya.

Soelarko. 1985, Pengantar Foto Jurnalisti: Bandung: PT. Karya Nusantara.

Stokes Jane. 2006. How to Do Media and Cultural Studies Panduan Untuk Melaksanakan Penelitian dalam Kajian Media dan Budaya. Yogyakarta; Bentang

Sutopo, H.B.2006. Metodologi Penelitian Kualitatif:Dasar Teori dan Terapannya Dalam Penelitian. Edisi-2.Surakarta: Universitas Sebelah Maret

Wiryanto. 2005. Pengantar Ilmu Komunikasi. Jakarta: Graha Ilmu

\section{Internet}

http:// Suardi Lubis.bogspot.co.id. Literasi Media Massa (accesed on 10 May 2020)

http:// Suardi Lubis.bogspot.co.id. Efek Media Massa Terhadap Budaya (accesed on10 Mei 2020)

http://azteza.wordpress.com/category/persepsi-foto. Accesed on 15 October 2019

https://www.kompasiana.com/wkurniawan/55090bc18133115a4fb1e1fc/tradisi-mudikdalam-bingkai-psikososial accesed on 15 October 2019

Sumber:https://islam.nu.or.id/post/read/116677/keutamaan-membaca-al-qur-andalamhadits-rasulullah. Accesed on 20 January 2020

CNN Indonesia.com, accesed on Thursday (234-2020). 